\title{
Influence of Ruminant Amniotic Fluid Fractions on Fibroblast and Lymphocyte Proliferation
}

\author{
Z. KOSTECKÁ, A. SOBEKOVÁ, J. BLAHOVEC \\ Department of Chemistry, Biology and Biochemistry, University of Veterinary Medicine, Košice, \\ Slovak Republic \\ Received May 26,2005 \\ Accepted May 11, 2006
}

\begin{abstract}
Kostecká Z., A. Sobeková, J. Blahovec: Influence of Ruminant Amniotic Fluid Fractions on Fibroblast and Lymphocyte Proliferation. Acta Vet. Brno 2006, 75: 169-174.

Different substances of amniotic fluid influence the cell proliferation and differentiation of developing animal fetus. The aim of this study was to determine the mitogenic effect of some peptide components of bovine amniotic fluid on bovine peripheral blood lymphocytes using methyl tetrazolium (MTT) colorimetric assay. The next aim of our work was to determine the mitogenic activity of ovine amniotic fluid fractions of peptide nature on benzo- $\alpha$-pyrene transformed BALB/c 3T3 mouse fibroblasts (BPA31 cells) by use of ${ }^{3} \mathrm{H}$-thymidine incorporation into nucleus DNA and in conclusion, to compare the mitogenic activity of ruminant amniotic fluid fractions on different indicator cells. According to our study, inhibiting effect was found only in the case of separated bovine amniotic fluid (Peak I) and ovine amniotic fluid (B fraction). On the other hand, we have observed activation of lymphocytes by other fraction of bovine amniotic fluid (Peak II) and also of BP- A31 cells by fraction A in case of ovine amniotic fluid. The proliferation of peripheral lymphocytes was not significantly changed after the addition of natural bovine amniotic fluid likewise when the delipidated ovine amniotic fluid was added to BP-A31 cells, there was no effect on ${ }^{3} \mathrm{H}$-thymidine incorporation. Our results suggest that with testing the proliferation effect, the selection of indicator cells is of great importance since various cell types respond in different ways to the same substances.
\end{abstract}

Bovine amniotic fluid, ovine amniotic fluid, BP-A31 cells, peripheral blood lymphocytes, mitogenic activity, inhibition of cell proliferation

Amniotic fluid is rich in protein substances (hormones, cytokines, polypeptide growth factors), which influence cell proliferation and differentiation of developing foetus (Parvin et al. 1994; Tamatani et al. 1988). The immunomodulatory properties of amniotic fluid have been extensively demonstrated in humans, mice and rats (Yoshimura et al. 1991), and suggest that the regulatory activity of amniotic fluid may be crucial in regulating maternal immunity during pregnancy as well as neonatal responsiveness in the foetal and neonatal periods (Parvin et al. 1994). According to some observations the amniotic fluid plays an important role in the protection of foetuses from bacterial infections (Saito et al. 1993). In the contrary other investigators have found that human amniotic fluid (Lang et al. 1994), murine and rat amniotic fluid (Parvin et al. 1994) suppress mitogen-stimulated lymphocyte proliferation. It is known that certain functions of the immune system can be modulated by insulin-like growth factor-I and -II (IGF-I and IGF-II) present in amniotic fluid (Kooijman et al. 1992).

The purpose of this study was to estimate mitogenic activity of peptide substances present in ruminant amniotic fluid obtained by separation on Sephadex G-10. Bovine peripheral blood lymphocytes and benzo- $\alpha$-pyrene transformed BALB/c 3 T3 mouse fibroblasts (BPA31 cell line) were used as indicator cells.

\section{Materials and Methods}

Collection and fractionation of amniotic fluid

Amniotic fluid was obtained by laparotomy, hysterotomy and puncture of amniotic sac of sheep in $10^{\text {th }}$ week of pregnancy and cows in $16^{\text {th }}$ week of pregnancy (species differences can be neglected because the stages of developing

Address for correspondence:

MVDr. Zuzana Kostecká, PhD.

Katedra chémie, biológie a biochémie

Univerzita veterinárskeho lekárstva

Komenského 73,041 81 Košice, Slovak Republic
Phone: +421556335621, extention 22

Fax: +421556334768

e-mail: kostecka1@azet.sk

http://www.vfu.cz/acta-vet/actavet.htm 


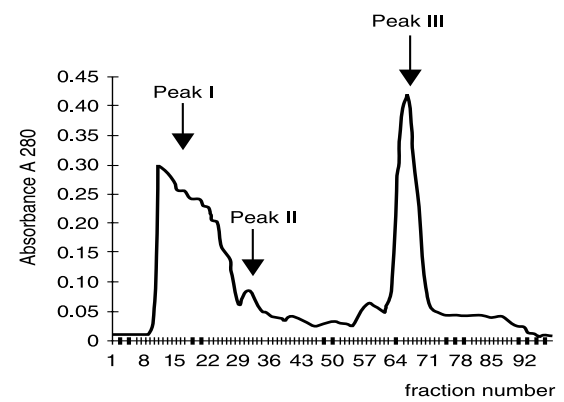

Fig. 1. Gel chromatography of bovine amniotic fluid on Sephadex G-10 $(2 \times 45 \mathrm{~cm})$, elution in $0.04 \mathrm{~mol}_{1 .}^{-1} \mathrm{NH}_{4} \mathrm{HCO}_{3}$ at a flow rate of $9.5 \mathrm{ml}^{-1}$. The content of peptides was determined by measuring the absorbance at wave-length of $280 \mathrm{~nm}$.

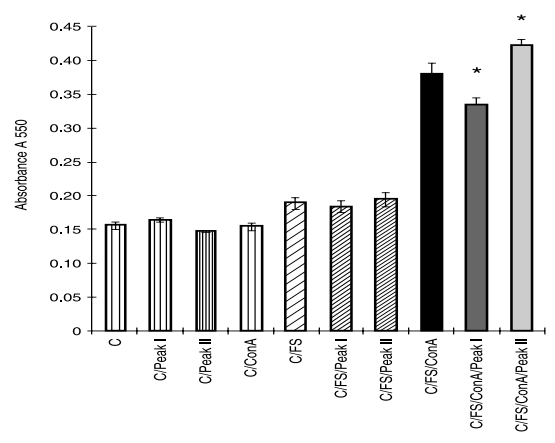

Fig. 3. Proliferation of peripheral blood lymphocytes in the presence of ConA and fractions obtained by gel filtration (Peak I and Peak II). Results are shown as means of three replicates. C- cells in complete medium, $\mathrm{C} / \mathrm{ConA}, \mathrm{C} / \mathrm{Peak}$ I and C/Peak II - cells in complete medium supplemented with $10 \mu \mathrm{g} . \mathrm{ml}^{-1}$ of ConA, Peak I or Peak II, C/FS - cells in the complete medium supplemented with $10 \%$ foetal calf serum, C/FS/ConA, C/FS/Peak I and C/FS/Peak II - cells in the complete medium supplemented with of foetal calf serum and ConA, Peak I or Peak II, C/FS/ConA/Peak I or $\mathrm{C} / \mathrm{FS} / \mathrm{ConA} / \mathrm{Peak}$ II - cells in complete medium supplemented with foetal calf serum, ConA, Peak I or Peak II.

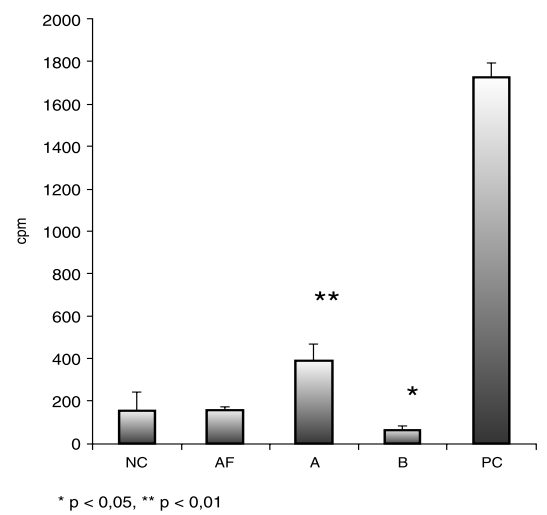

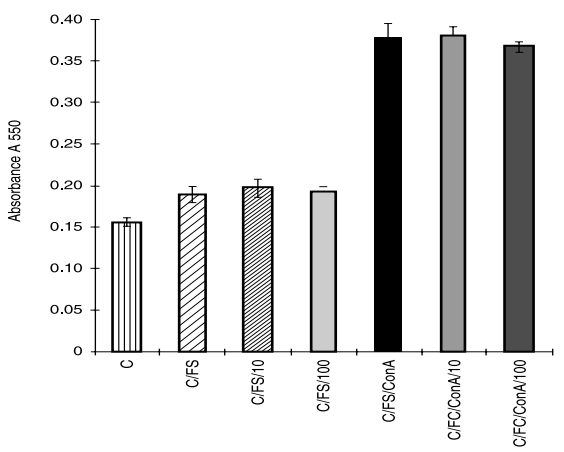

Fig. 2. Proliferation of peripheral blood lymphocytes in the presence of natural bovine amniotic fluid. Results are shown as the means of three replicates. $\mathrm{C}$ - cells in complete medium, C/FS - cells in the complete medium supplemented with $10 \%$ of foetal calf serum, $\mathrm{C} / \mathrm{FS} / \mathrm{ConA}$ - cells in the complete medium supplemented with $10 \%$ of foetal calf serum and $10 \mu \mathrm{g} . \mathrm{ml}^{-1}$ of ConA, C/FS/10 or C/FS/100 - cells in complete medium supplemented with foetal calf serum and natural amniotic fluid diluted 10 times or 100 times, $\mathrm{C} / \mathrm{FS} / \mathrm{ConA} / 10$ or $\mathrm{C} / \mathrm{FS} / \mathrm{Con} \mathrm{A} / 100$ - cells in complete medium supplemented with foetal calf serum, ConA and natural amniotic fluid diluted 10 times or 100 times.

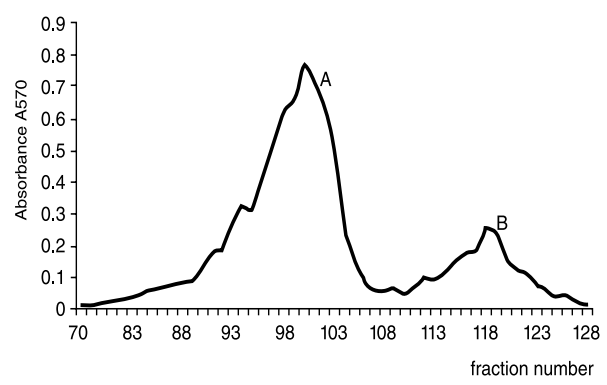

Fig. 4. Gel chromatography of ovine amniotic fluid on Sephadex G-10 column $(5 \times 70 \mathrm{~cm})$, elution in 0.04 mol. $1^{-1} \mathrm{NH}_{4} \mathrm{HCO}_{3}$ at a flow rate of $12 \mathrm{ml}^{-1}$. Fractions were determined by ninhydrin reaction (A 570).

Fig. 5. Mitogenic activity of ovine amniotic fluid. NC negative control (cells in complete medium), AF - nonseparated ovine amniotic fluid, A, B - fractions obtained by gel chromatography on Sephadex G-10, PC - positive control (cells in complete medium supplemented with $6 \%$ foetal calf serum). 


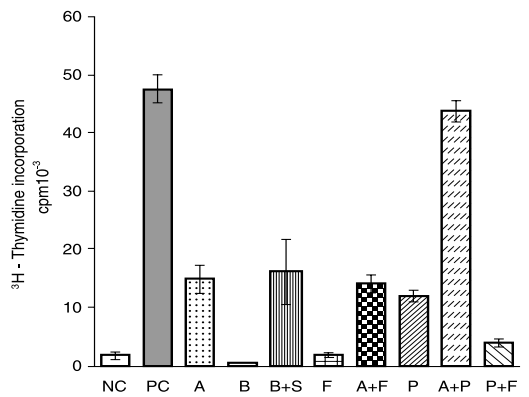

Fig. 6. Effect of Sephadex G-10 column fractions (the final concentrations were $25 \mu \mathrm{g} . \mathrm{ml}^{-1}$ ) on ${ }^{3} \mathrm{H}$-thymidine incorporation by BP-A31 cells. At the same time, the effect of tetradecanoyl phorbolacetate (TPA) was determined, alone and in combination with fraction A. The inhibition of the mitogenic effects of TPA (100 ng. $\left.\mathrm{ml}^{-1}\right)$ and of fraction A by forskolin $\left(10^{-5} \mathrm{~mol}^{-1}\right)$ were also assayed. Foetal bovine serum $(6 \%)$ was used as positive control and serum-free MEM $\alpha$ as negative control. Results are expressed as means \pm SD of triplicate cultures. The experiment was repeated twice with similar results. NC - negative control, $\mathrm{PC}$ - positive control, A,B - fractions A, B, F- forskolin, P- TPA.

ovine and bovine foetuses are approximately the same). The samples were delipidated with chloroform and stored in a lyophilized form. Diluted sample was loaded into a Sephadex G- 10 column $(2 \times 45 \mathrm{~cm}$ for bovine and $5 \times 70$ $\mathrm{cm}$ for ovine amniotic fluid). Elution was performed using $0.04 \mathrm{~mol}^{-1} \mathrm{NH}_{4} \mathrm{HCO}_{3}$ at a flow rate $9.5 \mathrm{ml} \cdot \mathrm{h}^{-1}$ (bovine amniotic fluid) and $12 \mathrm{ml} \cdot \mathrm{h}^{-1}$ (ovine amniotic fluid). The content of peptides was determined by measuring of the absorbance at $280 \mathrm{~nm}$ and by ninhydrin reaction. Natural amniotic fluid of cow nature - diluted 10 times and 100 times with complete culture medium RPMI-1640, and fractions of the first and second peak were tested for mitogenic activity.

Mitogen - induced proliferation of peripheral blood lymphocytes

Bovine peripheral blood lymphocytes were obtained by centrifugation using Histopaque-1077. Isolated lymphocytes $\left(3.5 \times 10^{6}\right.$ cells.ml ${ }^{-1}$, in triplicates $)$ suspended in the complete culture medium (RPMI-1640 with 100 units of penicillin and $100 \mu \mathrm{g}$ of streptomycin per $1 \mathrm{ml}$ plus $2 \mathrm{mmol} \cdot \mathrm{I}^{-1}$ of glutamine, without phenol red) were added into 24-well flat-bottom plastic plates in a final volume of $1 \mathrm{ml}$. Some wells were supplemented with $10 \%$ of foetal calf serum (FS). Concanavalin A (Con A) and fractions of amniotic fluid after gel filtration (Peak I, Peak II) were diluted in the complete culture medium and added into the wells at a final concentration of $10 \mu \mathrm{g} \cdot \mathrm{ml}^{-1}$. Mitogenic activity of the amniotic fluid $(10 \mu \mathrm{l})$ and its fractions was estimated using optimised MTT colorimetric assay described by Blahovec and Sobeková (2001). Determination was made three times in triplicates.

\section{Fibroblast proliferation}

Mouse BP-A31 fibroblasts were maintained in minimal essential medium modification $\alpha(\mathrm{MEM} \alpha)$ supplemented with $6 \%$ foetal calf serum (FS) in a humidified air/ $\mathrm{CO}_{2}(5 \%)$ atmosphere. For the detection of mitogenic activity, $20 \times 10^{3}$ cells were seeded per well in 24 flat bottom well boxes. After $24 \mathrm{~h}$, the medium was replaced with $1 \mathrm{ml} \mathrm{MEM} \alpha$ plus $2.5 \mu \mathrm{mol}^{-1} \mathrm{FeSO}_{4}$ and the cells were allowed to enter quiescence for additional $24 \mathrm{~h} .{ }^{3} \mathrm{H}$-thymidine $(2 \mu \mathrm{Ci})$ was added to the wells, together with column fractions to be tested. After $24 \mathrm{~h}$, the incorporation was terminated by acidification with $1 \mathrm{~mol} \cdot \mathrm{l}^{-1}$ ascorbic acid. The cells were fixed and washed with $5 \%$ trichloroacetic acid and solubilized in $0.1 \mathrm{~mol} \cdot \mathrm{l}^{-1} \mathrm{NaOH}$ for counting in a liquid scintillation spectrometer. Forskolin $\left(10^{-5} \mathrm{~mol} \cdot \mathrm{l}^{-1}\right)$ and tetradecanoyl phorbolacetate $\left(100 \mathrm{ng} \cdot \mathrm{ml}^{-1}\right)$ were used to investigate the role of protein kinase $\mathrm{A}$ and protein kinase $\mathrm{C}$ signalling pathways.

Statistical analysis

The results are given as means \pm SD. Statistical significance of differences between the obtained results was evaluated by the Student's $t$-test.

\section{Results}

Bovine amniotic fluid was fractionated by gel chromatography into three peaks (Fig. 1). Non-fractionated amniotic fluid and peptides from Peak I and Peak II were tested for mitogenic activity. Fig. 2 shows that ConA-induced proliferation of peripheral lymphocytes was not significantly changed after the addition of natural bovine amniotic fluid. However, fractions of amniotic fluid obtained by gel chromatography showed significantly different activity (Fig. 3). Inhibiting effect was found in the case of separated amniotic fluid (Peak I). On the other hand, we have observed activation of lymphocytes by other fraction of amniotic fluid (Peak II). Peak III had no effect (data not shown).

When the delipidated ovine amniotic fluid was added to BP-A31 cells, there was no effect on ${ }^{3} \mathrm{H}$-thymidine incorporation. However, after gel filtration on Sephadex G-10 (Fig. 4), the fraction eluted in the void volume (fraction A) was able to initiate the cell cycle in BP-A31 cells, in contrast, fraction eluted in the total volume of the column (fraction B) inhibited the cell cycle (Fig. 5). 
In order to obtain information concerning the functional characteristics of the growth factor(s) responsible for the observed mitogenic effect of fraction $\mathrm{A}$, we tested the activity of these fractions in the presence of tetradecanoyl phorbolacetate (activator of protein kinase C) or forskolin (activator of adenylate cyclase). Forskolin did not alter the mitogenic activity of fraction A, whereas it abolished the effect of TPA (Fig. 6). The activities of fraction A and TPA were approximately additive.

\section{Discussion}

During the rapid development of the embryo and foetus peptide growth factors are associated with tissue induction, the clonal growth of stem-cell populations, and the appearance of differentiated function in the presumptive organs. Insulin-like growth factorI and -II (IGF-I and -II) are the polypeptide growth factors that are potent mitogens for cells derived from all primitive germ layers. The IGFs appear early in embryogenesis during and after the condensation of presumptive organs and tissues and they are involved in growth and differentiation of dog dental pulp cells (Onishi et al. 1999), in proliferation and differentiation of myoblasts, chondrocytes and hematopoetic cells (Zumkeller 2002) and brain cell types (Hill 1989).

It is known that amniotic fluid contains insulin-like growth factors (IGF-I and -II) and their precursor forms (fraction A) besides other growth factors (Blahovec et al. 2001). IGF-I is associated to specific binding protein, IGFBP-1 (Nonoshita et al. 1994). This binary complex not only prolongs biological half-life of IGF-I and transports it to the target cells, but also decreases or eliminates its biological activity ( Liu et al. 1991). In our experiment, non-fractionated ovine amniotic fluid had no effect on proliferation of BP-A31 cells. However, after gel chromatography, peptide molecules of fraction A caused initiation of BPA31 cell division. This mitogenic activity displayed the characteristics of IGF because it was not inhibited by forskolin (inducer of adenylate cyclase) and it was additive with activity caused by phorbolesters. The void volume fraction A contains all molecules with $M_{r} \geq 700$ $\mathrm{Da}$, it means that also IGF-I and -II (peptide molecules with molecular weight of $7.6 \mathrm{kDa}$ and $7.4 \mathrm{kDa}$, respectively), precursor forms of IGF-II (17 - $30 \mathrm{kDa})$ and IGFBPs (40 - 45 $\mathrm{kDa}$ ) are present there (Blahovec et al. 2001). Fraction B contains small molecules with $\mathrm{M}_{\mathrm{r}} \leq 700 \mathrm{Da}$ and these peptides inhibited the proliferation of chemically transformed mouse fibroblasts, but did not influence the proliferation of carcinoma cell line $\mathrm{MCF}_{7}$ (data not shown).

Suppression of the ConA-induced proliferation of splenic lymphocytes and thymocytes has been shown with murine amniotic fluid (Parvin et al. 1994). Down-modulatory activity has been found also for human, murine and rat amniotic fluid when the peripheral mononuclear cells were used as target cells (Lang et al. 1994; Parvin et al. 1994). Normal freshly collected human lymphocytes expressed mRNAs for both IGF-I receptor and IGF-II receptor but no expression of the corresponding growth factors was detectable. After stimulation with phytohaemagglutinin the lymphocytes, however, expressed both IGF-I and IGF-II (Nyman and Pek onen 1993). IGF- I and IGF-II also augmented the lectin-induced proliferation of purified T lymphocytes (Kooijman et al. 1992). In our work, ConA - induced proliferation of peripheral lymphocytes was inhibited by substances present in Peak I of separated bovine amniotic fluid and activated by smaller peptide molecules (Peak II).

Our results are interesting because we have obtained one fraction of amniotic fluid with stimulatory properties and another one with inhibitory effects on fibroblasts but their effects are absolutely opposite in case of lymphocytes used as indicator cells. It is known that the same growth factor can act differently on the different cell types, can act differently at different concentrations or at different times on the same cell type (McKay 1993). 


\section{Vplyv frakcií amniónovej tekutiny prežúvavcov na proliferáciu fibroblastov a lymfocytov}

Proliferácia a diferenciácia buniek vyvíjajúceho sa plodu je ovplyvňovaná rozličnými látkami prítomnými v amniónovej tekutine. Cielom našej práce bolo stanovit mitogénny účinok niektorých látok peptidovej povahy z bovinnej amniónovej tekutiny na periférne lymfocyty kolorimetrickým metyltetrazóliovým testom a stanovenie mitogénnej aktivity peptidových frakcií ovčej amniónovej tekutiny na chemicky transformované BALB/c 3T3 myšie fibroblasty (bunky BP-A31) meraním rádioaktivity ${ }^{3} \mathrm{H}$-tymidínu inkorporovaného do DNA buniek. Na základe týchto meraní sme porovnávali mitogénnu aktivitu frakcií amniónovej tekutiny prežúvavcov v rovnakom štádiu gravidity na rôzne typy buniek. Z výsledkov našej práce vyplýva, že inhibičný účinok bol dokázaný u frakcií píku I bovinnej amniónovej tekutiny a frakcie B ovčej amniónovej tekutiny. Na druhej strane bola pozorovaná aktivácia lymfocytov frakciami píku II a proliferácia buniek BP-A31 frakciou A ovčej amniónovej tekutiny. Proliferácia periférnych lymfocytov nebola ovplyvnená prídavkom prirodzenej hovädzej amniónovej tekutiny podobne ako ked delipidovaná ovčia amniónová tekutina suplementáciou k bunkám BP-A31 nevyvolala inkorporáciu ${ }^{3}$ H-tymidínu do DNA indikátorových buniek. Na základe našich výsledkov možno konštatovat, že pri testovaní proliferačného účinku je velmi dôležitý výber indikátorových buniek, nakolko rôzne typy buniek reagujú na rovnaké látky odlišným spôsobom.

\section{Acknowledgements}

This work was supported by the Scientific Grant Agency of the Slovak Republic - VEGA (Grant No. 1/0616/03).

\section{References}

BLAHOVEC J, KOSTECKÁ Z, LACROIX MC, CABANIE L, GODEAU F, MESTER J, CAVAILLE F 2001: Mitogenic activity of high molecular weight forms of insulin-like growth factor-II in amniotic fluid. J Endocrinol 169: $563-572$

BLAHOVEC J, SOBEKOVÁ A 2001: The optimization of the rapid colorimetric assay for the growth and proliferation of peripheral blood lymphocytes. Folia veter 45: $35-38$

HILL DJ 1989: Growth factors and their cellular actions. J Reprod Fert 85: 723-734

KOOIJMAN R, WILLEMS M, RIJKERS GT, BRINKMAN A, van BUUL- OFFERS SC, HEIJNEN CJ, ZEGERS BJ 1992: Effects of insulin-like growth factors and growth hormone on the in vitro proliferation of T lymphocytes. J Neuroimmunol 38: 95-104

LANG AK, SEARLE RF 1994: The immunomodulatory activity of human amniotic fluid can be correlated with transforming growth factor - beta 1 and beta 2 activity. Clin Exp Immunol 97: 158-163

LIU L, BRINKMAN A, BLAT C, HAREL L 1991: IGFBP-1, an insulin-like growth factor binding protein, is a cell growth inhibitor. Biochem Biophys Res Commun 174: 673-679

McKAY IA 1993: Types of growth factor activity: detection and characterization of new growth factor activities. In: McKAY, IA and LEIGH I (Eds): Growth factors. A practical Approach. Oxford University Press, OxfordNew York- Tokyo, pp.1-12

NONOSHITA LD, WATHEN NC, DSUPIN BA, CHARD T, GIUDICE LC 1994: Insulin-like growth factors (IGFs), IGF-binding proteins (IGFBPs) and proteolyzed IGFBP-3 in embryonic cavities in early human pregnancy: Their potential relevance to maternal-embryonic and fetal interactions. J Clin Endocrin Metab 79: 1249-1255

NYMAN T, PEKONEN F 1993: The expression of insulin-like growth factors and their binding proteins in normal human lymphocytes. Acta Endocrinol (Copenh) 128: 168-172

ONISHI T, KINOSHITA S, SHINTANI S, SOBUE S, OOSHIMA T 1999: Stimulation of proliferation and differentiation of dog dental pulp cells in serum-free culture medium by insulin-like growth factor. Arch Oral Biol 44: 361-371

PARVIN M, ISOBE K, ZOHREH H, GOTO S, NAKASHIMA I, TOMODA Y 1994: Amniotic fluid enhances allogeneic cytotoxic $\mathrm{T}$ cell responses, whereas it suppresses mitogen-stimulated lymphocyte proliferation. Microbiol Immunol 38: 327-330

SAITO S, KASAHARA T, KATO Y 1993: Elevation of amniotic fluid IL-6, IL-8 and granulocyte colony stimulating factor in term and preterm parturition. Cytokine 5: 81-88

TAMATANI T, TSUNODA H, IWASAKI H, KANEKO M, HASHIMOTO T, ONOZAKI K 1988: Existence of both IL-1 alpha and beta in normal human amniotic fluid: unique high molecular weight form of IL-1 beta. Immunology 65: 337-342 
YOSHIMURA N, MATSUI S, HAMASHIMA T, LEE C, OHSAKA Y, HIRAKAWA K, OKA T 1991: Mechanism of immunosuppresssive action of the amniotic fluid on lymphocyte activation. Transplantation Proceedings 23: 185-186

ZUMKELLER W 2002: The insulin-like growth factor system in hematopoietic cells. Leuk Lymphoma 43: 487-491 